University of Michigan Law School

University of Michigan Law School Scholarship Repository

\title{
Should a Correct Verdict Be Set Aside Because the Jury Failed to Follow Erroneous Instructions?
}

\author{
Edson R. Sunderland \\ University of Michigan Law School
}

Available at: https://repository.law.umich.edu/articles/967

Follow this and additional works at: https://repository.law.umich.edu/articles

Part of the Civil Procedure Commons, and the Litigation Commons

\section{Recommended Citation}

Sunderland, Edson R. "Should a Correct Verdict Be Set Aside Because the Jury Failed to Follow Erroneous Instructions?" Mich. L. Rev. 17 (1919): 592-4.

This Response or Comment is brought to you for free and open access by the Faculty Scholarship at University of Michigan Law School Scholarship Repository. It has been accepted for inclusion in Articles by an authorized administrator of University of Michigan Law School Scholarship Repository. For more information, please contact mlaw.repository@umich.edu. 
Should a Correct Verdict be set aside because the Jury Failed to Foliow ERRongous INSTRUCMTONS?-One of the common grounds of a new trial is that the verdict is contrary to law. What law is meant,-the law as it really is, or the law that was given to the jury by the court's instruction? Most cases hold to the latter view. It is the duty of the jury to take the law from the court, whether the court in so giving it is right or wrong. Hence, the jury violate their duty if they fail to follow instructions, even if the instructions are wrong, and a verdict based on a breach of the jury's duty cannot be allowed to stand, even though intrinsically correct. Talley v. Whitlock, (Ala., 1917) 73 So. 976; Gartner v. Mohan, 39 S. D. 202; Yelloze Poplar Lumber Co., v. Bartley, I64 Ky., $\nabla 63$; Soderburg v. Chicago St. P. M. \& $O$. Ry. Co, 167 Ia., 123; Freel v. Pietzsch, 22 N. D., II3; Barton v. Shull, 62 Neb., 570; Dent v. Bryce i6 S. C., I4; Murray v. Heinze, I7 Mont., 353.

The argument on which this rule is founded is well expressed by the Supreme Court of Montana in Murray v. Heinze, supra, where the court said: "But counsel for the appellant contend that, the instruction being erroneous, the court erred in setting aside the verdict because of the fact that the jury wholly disregarded it .... This is the first time it has been seriously contended in this court that the jury have the right to determine the law in an ordinary suit at law and to absolutely disregard the instructions of the court on the ground that, in the opinion of the jury, the instructions of the court are erroneous. If the contention of the appellant is to be upheld, what may we not anticipate as the result in the administration of the law in this state? If the jury may rightfully invade the province of the court, why may not 
the court retaliate by invading the province of the jury in determining questions of fact? As counsel for the respondent suggest, if the contention of the appellant is correct, then logically there is-an appeal in all cases upon questions of law from the trial court to the jury. And as counsel for respondent further suggest in their argument, if the jury may determine the law, an attorney arguing the case may say to the jury: "The court will charge you that the law is so and so, but I say to you the court is wrong!'"

But now and then we find a case where the court refuses to be terrorized by this reasoning. Such a case is Public Utilities Co., v. Reader (Ind. App. 1919) $122 \mathrm{~N}$. E., 26. The court held that a verdict was not "contrary to law" merely because is was contrary to an erroneous instruction given to the jury. And with the Indiana appellate court stand a few others who take the same view. Lucken v. Lake Shore \& M.S. R. R. Co., 248 Ill., 377; Pitts v. Thrower, 30 Ga., 2I2; Van Vacter v. Brewster, Solomon \& Co., I Sm. v. M. (Miss.), 400; Cockrane v. Winburn, 13 Tex. 143.

The argument of the majority sounds more like an excuse than a reason. Nobody claims that the jury has the right to pass on the law, any more than that the court has the right to do a great many things which it constantly does and which constitute error in the trial of cases. But if it appears that the jury was right on the law and the court was wrong, what should be done about it?

The real question is, what is the purpose of the trial,--to get a correct result, or to get it in a correct manner? Thousands of errors are committed every day by our courts in rulings made at the trial of cases, but they do not produce new trials unless prejudice has resulted from them. It is everywhere agreed that technical error and prejudicial error are very different things. Error which does not affect the final result is constantly ignored. There is no potency in error as such, any more than in carelessness as such. One can be as careless as he pleases, and if no harm comes from it there is no liability. Courts may make endless errors in trying cases, but if no harm comes from them they are very properly disregarded.

There is no apparent reason why the particular error here discussed should stand on any different basis from other errors. The dreadful spectacle of an attorney appealing to the jury to overrule the court in the law, which the Montana court so tragically suggests, is nothing but a bogie, for it is perfectly clear that such an appeal would constitute so flagrant a contempt of court that it could be instantly checked if anyone had the hardihood to attempt it. That being so, the rule requiring a correct verdict to be set aside when contrary to bad instructions, must be based upon the need of punishing the jury for disobedience. But setting aside the verdict does not punish the jury, -it only penalizes the party who gets the verdict. It could perhaps be suggested that the acceptance of such verdicts might develop insubordination among juries. But no such result has been noted in jurisdictions where they are accepted. The imposition of heavy penalties is a mark of social mal-adjustment. It was once thought that the prevention of insubordination among citizens required capital punishment for a score of petty crimes; that military discipline could be maintained only by frightful 
punishments for the slightest cases of disobediences. Judges long contended that the allowance of amendments would put such a premium on careless pleading that the whole system of legal procedure would go to ruin. All that is being gradually discarded. Destroying verdicts as a means of disciplining inattentive or disobedient juries is on a par with shooting hostages to subdue a recalcitrant population.

The truth appears to be that we have in this rule merely a survival of the once common doctrine of reversal for technical error, coupled possibly with an inherited fear that the judges, once the representatives of the king and the privileged classes, might lose their prestige by acknowledging that a jury could ever be right when it differed from the court. But we are rapidly losing our veneration for conventionality, and we no longer canonize rules of procedure in theory even though in practice we still sometimes insist that a good result is bad because it was not produced in the orthodox way. If the courts are to merit public confidence they must think more about their duty to the people and less about themselves, more about the justice of their results and less about the regularity of their methods.

Exaggerated self-consciousness, in an institution as in an individual, is always likely to produce excessive formalism. The more fully the interests of the litigants occupy the attention of the court, the more completely will technicalities of procedure lose their power to obstruct.

E. R. S. 